\title{
Immunoglobulin G Subclass 1 Measurement
}

National Cancer Institute

\section{Source}

National Cancer Institute. Immunoglobulin G Subclass 1 Measurement. NCI Thesaurus.

Code C122127.

The determination of the amount of immunog lobulin G subclass 1 present in a sample. 